\title{
Consent, common law and native title
}

Stephen W Robson

Native title refers to the recognition at common law of the rights of Aboriginal and Torres Strait Islander peoples to their traditional lands and waters. ${ }^{1}$ Australia's basis for this recognition occurred with the High Court's 1992 decision in Mabov Queensland (No 2). ${ }^{2}$ Ten years later, sitting down and reaching agreement with traditional owners is now advocated as a preferable way of developing business in regional Australia. ${ }^{3}$ At another level though, the differences between negotiation rights and consent have become blurred and misunderstood.

In reviewing how this came about I'll begin by locating this issue in a broader context. The foundation of common law is associated with the two centuries following the Norman Conquest of England in 1066 when law and government administration separated. ${ }^{4}$ Australia embraced common law as a concomitant of the British colonisation process, an aspect affirmed in the Mabo decision. ${ }^{5}$

The law of consent has a long presence in common law. Applied to breach of contract disputes, its earliest usage is identified around 1250. The word derives from two roots, 'con' meaning together and part of the verb 'sentire' meaning to feel, think or judge. In brief, it refers to a concurrence of wills. More precise definitions are required though in order to differentiate it from other relevant notions, e.g. submission, acquiescence, duress, deception and permission. It should also be noted that its meaning can vary, depending upon its legal context. ${ }^{6}$

At common law consent was embraced as a protection against the King's use of arbitrary and unilateral power. This is expressed in the statement that the Crown 'cannot take away, abridge, or alter any liberties or privileges granted by him or his predecessors, without the consent of the individuals holding them'. In particular, a grant cannot be superseded by a subsequent inconsistent grant made by another person. ${ }^{8}$

Making the analogy with native title, these statements provide authority for limiting the Crown's power to extinguish or impair it without the consent of the titleholder. Hence in this context, consent is about titleholders exercising their free will over what happens to their title. If the Crown exercises a unilateral power to extinguish a title it is overriding the will of the titleholder. While a right to negotiate provides some opportunity to ameliorate the

${ }^{1}$ Bartlett 2000: 3, 23.

2 (1992) 107 ALR 1.

${ }^{3}$ Huggins and Chaney 2002: 11.

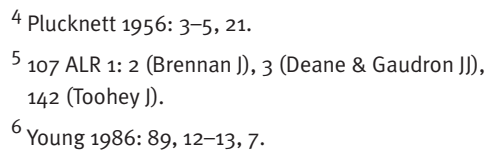

7 Chitty 1937 [1820]: 125.

${ }^{8}$ See authorities cited in Western Australia $v$ Commonwealth (1995) 128 ALR 1 at 25; also Bartlett 2000: 28. 
circumstances, it is not consent's essential feature. Consent does not revolve around participation in decision-making. Rather consent centres on the right of titleholders to control what happens on their land.

\section{The Mabo decision}

So why is it that this authority has thus far not been accepted as integral to Australia's native title doctrine? One reason derives from the nature of the Mabo decision. Here the Meriam People sought recognition of their traditional connections to the Murray Islands. In their final formulation before the court the plaintiffs stated that their title was qualified by being subject to the capacity of the Queensland government to 'extinguish it' by 'clear and plain legislation'. In their submission they argued that the power to extinguish their title had not been exercised.? Arguing against recognition of title, the Queensland Government argued that 'no right or interest in any land in the territory could ... be possessed by any other person unless granted by the Crown'. ${ }^{10}$ Thus the limits on the Crown's power to extinguish native title did not become a main focus.

A second, and more important, reason is that in Mabo the majority of the court accepted that the Crown held a power to extinguish native title unilaterally. Justice Brennan expressed this clearly in his summary of general rules concerning executive extinguishment of native title. Here he states that:

[where] the Crown has validly alienated land by granting an interest that is wholly or partially inconsistent with a continuing right to enjoy native title, native title is extinguished to the extent of the inconsistency. Thus native title has been extinguished by grants of estates of freehold or of leases but not necessarily by the grant of lesser interests (eg authorities to prospect for minerals). ${ }^{11}$

Furthermore,

[where] the Crown has validly and effectively appropriated land to itself and the appropriation is wholly or partially inconsistent with a continuing right to enjoy native title, native title is extinguished to the extent of the inconsistency. ${ }^{12}$

A short statement provided by Mason CJ and McHugh J confirms that they also shared Justice Brennan's view. ${ }^{13}$ Justices Deane and Gaudron also held that the executive could extinguish native title by inconsistent Crown grant. However, they did consider that this would be 'wrongful' and could create a valid claim for compensatory damages. ${ }^{14}$ They did not, however, explore the basis for this 'wrongful act' and whether or not they consider consent to be a factor.

Hence five judges recognising native title at common law (Mason CJ and Brennan, McHugh, Deane and Gaudron JJ) upheld the Crown's power to unilaterally deny or extinguish it by inconsistent grant. ${ }^{15}$ This stance then is incompatible with one where extinguishment could only occur with the consent of the titleholders. However, in their judgments none considered

\footnotetext{
9 (1992) 107 ALR 1: 138 (Toohey J).

10 (1992) 107 ALR 1: 16.

${ }^{11}$ (1992) 107 ALR 1: 51 para 4.
}

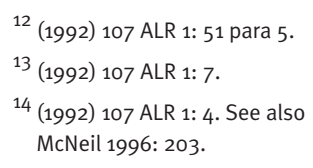
McNeil 1996: 203.

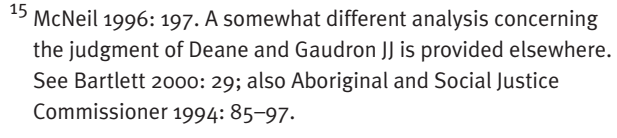

15 McNeil 1996: 197. A somewhat different analysis concerning the judgment of Deane and Gaudron JJ is provided elsewhere. See Bartlett 2000: 29; also Aboriginal and Social Justice Commissioner 1994: 85-97. 
those native title cases supporting the latter interpretation. Nor did they examine common law precedent more broadly regarding the Crown's power to extinguish pre-existing customary land rights. Examining this matter Canadian legal scholar Kent McNeil concludes that the 'rule that native title can be extinguished by inconsistent grant is not supported by the common law, and in fact contradicts fundamental common law principles. ${ }^{16}$

In Mabo, Toohey J was alone in referring to cases where the consent of the titleholders was upheld. ${ }^{17} \mathrm{He}$ cites the cases of Worcester $v$ Georgia where Marshall CJ found that the Crown had 'exclusive right of purchase', but this was not based upon a 'denial of the right of the purchaser to sell'. ${ }^{18}$ Similarly, in $R v$ Symonds Chapman J said that:

Whatever may be the opinion of jurists as to the strength or weakness of the Native title ... it cannot be too solemnly asserted that it is entitled to be respected, that it cannot be extinguished (at least in times of peace) otherwise than by the free consent of the Native occupiers. ${ }^{19}$

Justice Toohey also referred to those cases providing support for the Crown exercising the power of extinguishment unilaterally. Examining the three rationales advanced to support this, he finds them wanting. ${ }^{20}$ However, he too did not fully investigate the applicability of consent, instead finding that extinguishment in the case had not occurred. ${ }^{21}$

\section{Political response}

A third reason for the marginalisation of consent lies with the subsequent political response. The government did not establish a process, or processes, to complete the work begun by the High Court. Is the power to extinguish native title exercisable only with the consent of the titleholders? Or is this power exercisable unilaterally without account of the traditional titleholders' interests?22 These questions, posed by Toohey J in Mabo, were not addressed. Instead, the Keating government presumed the latter to prevail..$^{23}$

Furthermore, investigations were not made regarding other significant issues arising from Mabo. What limits exist on Crown power to extinguish legal rights to land? ${ }^{24}$ If, as the High Court recognised, native title survived the 'change of sovereignty', ${ }^{25}$ then wouldn't subsequently issued titles be invalid to the extent of their inconsistency with native title? Instead, the government presumed that where inconsistencies arose it would be native title that was extinguished. ${ }^{26}$

Fourthly, the way in which the Government treated the right to negotiate provisions blurred the understanding of consent. The Government's June 1993 Discussion Paper devotes a chapter to negotiation and consent. ${ }^{27}$ Its authors establish non-discrimination as a 'benchmark'. This principle seeks to ensure that when the rights of native titleholders are directly compared to those of other titleholders these are not deficient. The authors also acknowledge the possibility that '[i]n recognition of the special attachment of Aboriginal and Torres Strait Islander people to their land there could be additional rights of consent ... ${ }^{28}$ However, the authors argue that, rather than being adopted as a principle, consent should be applied in a more restricted fashion. Their justification relies on Australian experiences as providing legislative precedence for 'qualified consent'. ${ }^{29}$

\footnotetext{
${ }^{16}$ McNeil 1996: $197 . \quad 20$ (1992) 107 ALR 1: 151-2.

17 (1992) 107 ALR 1: 151-3. $\quad 21$ (1992) 107 ALR 1: 153-61.

18 (1832) 31 US 515, 544.

19 (1847) NZPCC 387, 390.

${ }^{23}$ Native Title Act 1993 (Cth): Preamble.

22 (1992) 107 ALR 1: $150 . \quad 24$ McNeil 1996: 216.

25 (1992) 107 ALR 1: 2

${ }^{26}$ Australian Government Solicitor 1998: C2.

${ }^{27}$ Ministerial Committee on Mabo 1993: 60-4.

${ }^{28}$ Ministerial Committee on Mabo 1993: 63.

${ }^{29}$ Ministerial Committee on Mabo 1993: 61-4.
} 
The approach in the 1993 Discussion Paper is unfortunate on three grounds. One is that the authors do not discuss the precedents in common law for the application of consent to the recognition of native title. Another is that in their discussion of examples they do not consider that the context had changed with Mabo. Furthermore, it is questionable whether one of the examples can really be described as 'qualified consent'. The use of consent in the Aboriginal Land Rights (Northern Territory) Act 1976 (Cth) is different from a right to negotiate, since the land councils hold a power to refuse exploration licences. ${ }^{30}$ Thus this should be more aptly described as an example of unqualified consent. Having transformed consent into a right to negotiate, this approach provided the basis for the Native Title Act 1993 (Cth).

The Act ${ }^{31}$ also links the right to negotiate provisions with special measures as understood in Article 1(4) of the International Convention on the Elimination of All Forms of Racial Discrimination. In December 1993 during the parliamentary debate over the legislation, Foreign Minister Gareth Evans justified this link on the grounds that these are rights 'not enjoyed by non-Aboriginal titleholders. ${ }^{32}$

However, the Convention indicates that:

[special measures are] taken for the sole purpose of securing adequate advancement of certain racial or ethnic groups or individuals requiring such protection as may be necessary in order to ensure such groups or individuals equal enjoyment or exercise of human rights and fundamental freedoms. ${ }^{33}$

The Convention also cautions to avoid the consequence that such measures 'lead to the maintenance of separate rights for different racial groups and that they shall not be continued after the objectives for which they were taken have been achieved'. ${ }^{34}$ This does not sit easily with Australia's approach since it refers to circumstances where the measures are temporary, and special is understood as something additional to existing rights.

Yet if consent is a right arising out of common law, like recognition, it is neither temporary nor special in the sense of a measure to overcome discrimination. Nor does its essential feature arise from comparisons with other titles, as suggested by the non-discrimination principle. Rather, it is a principle in its own right and essential to respecting the recognition of native title. Furthermore, Evans was incorrect. A right of consent for a titleholder when the Crown seeks to extinguish title is a right enjoyed in the community more broadly, and Aboriginal and Torres Strait Islander peoples should not be denied this equality. ${ }^{35}$

The subsequent political debate over the Howard Government's Native Title Amendment Bill further obscured the origins and understanding of these rights. One reason was that the Government portrayed the debate over the right-to-negotiate provisions as one between

\footnotetext{
${ }^{30} \mathrm{~s} .42$.

${ }^{31}$ Native Title Act 1993 (Cth): Preamble.

${ }^{32}$ Australia, Senate, 21 December 1993.

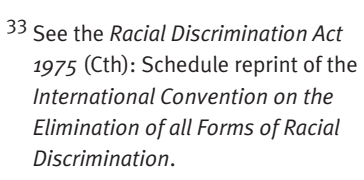

33 See the Racial Discrimination Act 1975 (Cth): Schedule reprint of the International Convention on the Elimination of all Forms of Racial Discrimination.

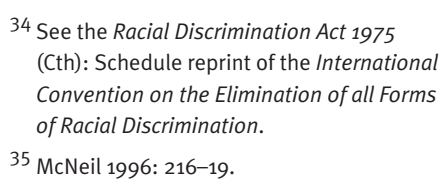

35 McNeil 1996: 216-19. 
supporters of substantive equality and those, like itself, who were inclined to apply formal equality. ${ }^{36}$ Those opposed to the changes largely accepted this terrain. ${ }^{37}$ As a result, the genesis of the right-to-negotiate provisions originating in consent did not become a focus for discussion.

Another reason for the lack of serious discussion of the genesis of the right-to negotiate provisions arising from consent arose from the political portrayal of 'special'. The Prime Minister campaigned to reject those rights that provide an 'advantage ... to one section of the Australian community over others' ${ }^{38}$ The result is that some now incorrectly associate a 'special measure' with some sort of unfair free kick. Its specific source as a measure adopted by the Keating Government to partially compensate Indigenous people in the face of sweeping extinguishment of native title has largely been forgotten.

\section{Conclusion}

The marginalisation of consent, then, has been reinforced by not one, but several, factors. The issue though is more than just an academic concern. A right to consent is also a value held by peoples and articulated when resisting arbitrary and unjust dispossession of their lands. During the debates over native title legislation several gatherings brought together people from many different Aboriginal and Torres Strait Islander communities. Meetings around the Peace Plan ${ }^{39}$ and in Eva Valley ${ }^{40}$ in 1993 both clearly expressed the desire that extinguishment of native title should not occur without the consent of titleholders. In the debate over the Howard Government's Native Title Amendment Bill the National Indigenous Working Group made plain that it did not consent to the changes. ${ }^{41}$ During this time these voices were not heard. Caution and inclination to protect customary rights did not prevail and measures to unilaterally extinguish native title were adopted. On the basis of what has been described above a grave injustice has been committed.

What possibilities are there, then, that this matter will be rectified and consent will form a more general basis to relations with Aboriginal and Torres Strait Islander peoples? Modification of the native title principles is one possibility. The absence of full and thorough consideration of consent in the Mabo case could invite a re-examination from either the court or parliament. Another possibility is that consent will be embraced through the push for a treaty/agreement. A virtue of this form over legislative solutions is that consent is embedded within its very framework. The core idea is that Australia's first peoples should have their distinct status and freedom respected through their consent to Australia's constitutional framework.

\section{Acknowledgments}

Thanks to Professor GD Meyers and Dr Ian Barns.

\footnotetext{
${ }^{36}$ Australia, House of Representatives 1998: 173.

37 For a detailed analysis of the amended right to negotiate provisions, see Meyers and Raine 2001.

${ }^{38}$ Australia, House of Representatives 1998: 6042.

39 See Tickner 2001: 112-33; Brennan 1995: 45-6.

${ }^{40}$ Eva Valley Statement 1993.

${ }^{41}$ See Australia, Senate 1998. The statement from the National Indigenous Working Group was 'read into the Hansard' by ALP Senator Nick Bolkus, Greens (WA) Senator Dee Margetts and Australian Democrat Senator John Woodley.
} 


\section{References}

Aboriginal and Social Justice Commissioner 1994 Native Title Report-January-June 1994, AGPS, Canberra.

Australia, House of Representatives 1998, Weekly Hansard, no 10: 6042, 3 July.

Australia, Senate 1993, Weekly Hansard, no 15: 5476, 21 December.

Australian Government Solicitor 1998, Native title: legislation with commentary by the Australian Government Solicitor, 2nd edn, Australian Government Solicitor, Canberra.

Bartlett, RH 2000, Native title in Australia, Butterworths, Chatswood NSW.

Brennan, Frank 1995, One land, one nation: Mabo: Towards 2001, University of Queensland Press, St Lucia, Queensland.

Chitty, J 1937 [1820], A Treatise on the law of prerogatives of the Crown, 19th edn, Sweet \& Maxwell, London.

Commonwealth of Australia 1998, Native Title Amendment Bill 1997: Explanatory Memorandum. House of Representatives, Canberra.

Eva Valley Statement 1993, as reprinted in M Goot and T Rowse 1994 (eds) Make a better offer: the politics of Mabo, Pluto Press Australia, NSW: 233.

Huggins, Jackie and Fred Chaney 2002, 'Building blocks, not roadblocks required', The Australian 3० May: 11

McNeil, Kent 1996, 'Racial discrimination and unilateral extinguishment of native title', Australian Indigenous Law Reporter 1(2): 181-220.

Meyers, GD and S Raine 2001, 'Australian Aboriginal land rights in transition (Part II): The legislative response to the High Court's native title decisions in Mabo v. Queensland and Wik v Queensland', Tulsa Journal of Comparative \& International Law 9(1): 95-167, available at http://www.lexis.com/ research/retrieve?, viewed 8 May 2002.

Ministerial Committee on Mabo 1993, Mabo: The High Court Decision on Native Title, Discussion Paper, AGPS, Canberra.

Plucknett, TFT 1956, A Concise history of the common law, 5 th edn, Butterworth \& Co, London.

Tickner, Robert 2001, Taking a stand, Allen \& Unwin, NSW.

Young, PW 1986, The law of consent, The Law Book Co Ltd, Sydney.

\section{Legislation}

Aboriginal Land Rights (Northern Territory) Act 1976 (Cth).

Native Title Act 1993 (Cth).

Racial Discrimination Act 1975 (Cth).

\section{Case law}

Mabo and Ors $v$ The State of Queensland (No 2) (1992) 107 ALR 1.

$R v$ Symonds (1847) NZPCC.

Western Australia v Commonwealth (1995) 128 ALR.

Worcester v Georgia (1832) 31 US 515, 544. 